Journal of Animal and Feed Sciences, 1, 1992, $213-221$

\title{
The effect of cut, stage of growth and wilting on nitrogenous compounds and protein solubility in grass silages
}

\author{
Z. M. Kowalski, J. B. Pyś and J. Kański \\ Department of Animal Nutrition, Agricultural University of Cracow \\ Al. Mickiewicza 24/28, 30-059 Kraków, Poland
}

(Received 16 July 1992; accepted 14 December 1992)

\begin{abstract}
Silages were made from two cuts of pasture grass (May-June vs. July), with two stages of growth within each cut (early vs. late) and three extents of wilting (unwilted - about. $21 \% \mathrm{DM}$, wilted $-38 \% \mathrm{DM}$, strongly wilted - 51\% DM). Silages were prepared in laboratory plastic silos containing about $60 \mathrm{~kg}$ of unwilted grass. Measured in 48 silages were total- $\mathrm{N}$, protein- $\mathrm{N}, \mathrm{ADIN}$, $\mathrm{N}-\mathrm{NH}_{3}$ and soluble-N in Wise Burroughs Mineral Buffer.

When expressed on a dry matter basis, all of the studied factors had a significant effect on nitrogenous compounds of silages $(P<0.05$ or $P<0.01)$, with the exception of ADIN $(P>0.05)$ and the effect of wilting on total-N $(P>0.05)$. On the other hand, when expressed as a percentage of total-N $(\% \mathrm{~N})$, of all of the factors studied, the extent of wilting caused the greatest changes. The content of protein- $\mathrm{N}$ increased $(\mathrm{P}<0.01)$ and soluble- $\mathrm{N}$ and $\mathrm{N}-\mathrm{NH}_{3}$ decreased $(\mathrm{P}<0.01)$ with increasing DM level. The protein of silages made in July was more soluble $(\mathrm{P}<0.05)$. Soluble-N as a percentage of total $\mathrm{N}$ was influenced by the DM content of fresh grass $(r=-0.86, P<0.01)$ and highly correlated with NPN percentage of total $N(r=0.83, P<0.01)$.
\end{abstract}

KEY WORDS: grass silage, protein, stage of growth, cut, wilting, solubility

\section{INTRODUCTION}

Ensiling of herbage causes unavoidable changes in nitrogenous compounds as the result of the action of plant proteases and bacteria in the silo (Oshima et al., 1978). Field wilting before ensiling, commonly practiced to improve silage quality, if done under adverse drying conditions, enhances the activity of plant enzymes and may negatively increase the proportion of NPN in herbage (Carpintero et al., 1979; Anderson, 1983; Gordon, 1989). It is generally assumed that silage NPN and soluble-protein $\mathrm{N}$ are rapidly utilized in the rumen (Thomas et al., 1985; Tamminga et al., 1991) and that the rapid release of ammonia can be one of the reasons for poor utilization of grass silage protein (Thomas et al., 1985). 
On the other hand, the quality of silage protein is influenced by grass maturity; as the crop matures its crude protein content falls, while soluble proteins continue to make up 75 to $85 \%$ of the crude protein (Lyttleton, 1973). Moreover, because of the higher proportion of leaves in young grass, it is easier to wilt, which may decrease the risk of adverse changes in protein before ensiling.

The aim of this study was to examine the effect of grass cut, its stage of growth and extent of wilting on nitrogenous compounds and protein solubility in grass silage, since a typical practice in Poland is to prepare grass silage either from the first or second cuts and wilting is gaining wider acceptance.

\section{MATERIAL AND METHODS}

\section{Silage preparation}

Twelve silages were prepared from a pasture sward, containing mainly perennial ryegrass (Lolium perenne), meadow fescue (Festuca pratensis) and cocksfoot (Dactylis glomerata) and harvested using a disc mower. Silages were made from the first and second cuts, harvested at two stages of growth within each cut: early on 8th May (pre-earing) and 13th July, and late on 2nd June (earing) and 26th July for the first and second cuts, respectively. Within each cut and stage of growth three extents of wilting were imposed: unwilted, wilted for 24 hours and strongly wilted for 36 hours. The herbages were ensiled in plastic containers, which with about $60 \mathrm{~kg}$ of fresh grass. There were 4 containers for each treatment, giving a total of 48 silos.

\section{Chemical analysis}

Grab samples of unwilted and wilted herbages were taken before ensiling at each cut and stage of growth. They were then frozen at $-15^{\circ} \mathrm{C}$ until analysis. Samples of silage were taken from each silo after 120 days of ensiling and stored at $-15^{\circ} \mathrm{C}$ until analysis.

Dry matter content in herbages and silages was determined in a forced-draught oven at $80^{\circ} \mathrm{C}$, correcting for volatile compounds in silages (Polska Norma, PN-74). Analyses for total-N, protein-N, ADIN, nitrate-N and water-soluble carbohydrates (WSC) were performed on oven dried samples. Total- $\mathrm{N}$ was determined by the $\mathrm{Kjeldahl}$ method and protein- $\mathrm{N}$ was described as the $\mathrm{N}$ insoluble in trichloro-acetic acid (Siddons et al., 1979). ADIN content was determined by the Goering et al. (1970) method and nitrate- $\mathrm{N}$ using a cadmium column (Polska Norma, PN-74). WSC content was analyzed by the method of Deriaz (1961). Ammonia-N in silages was determined in water extracts using Conway's procedure (Skulmowski, 1974). Protein solubility in $10 \%$ Wise 
Burroughs Mineral Buffer (WBMB) was performed by the method of Crooker et al. (1978) in which dried and ground (to pass a $1 \mathrm{~mm}$ sieve) samples of silages were incubated in $\mathrm{WBMB}$ at $40^{\circ} \mathrm{C}$ for 1 hour.

Chemical data were examined by analysis of variance with cut, stage of growth and wilting extent as main effects. Means were compared using Duncan's test.

\section{RESULTS}

Results of the effect of treatments on the chemical composition of herbage is given in Table 1 . First cut herbage had lower DM $(\mathrm{P}<0.05)$ and total-N

TABLE 1

The effect of cut, stage of growth ind extent of wilting on chemical composition of herbage for ensiling

\begin{tabular}{|c|c|c|c|c|}
\hline & $\begin{array}{l}\mathrm{DM} \\
(\%)\end{array}$ & $\begin{array}{l}\text { Total-N } \\
(\% \text { DM })\end{array}$ & $\begin{array}{l}\text { Protein- } N \\
(\% \text { total- } N)\end{array}$ & $\begin{array}{c}\text { WSC } \\
(\% \text { DM })\end{array}$ \\
\hline \multicolumn{5}{|l|}{ Cut } \\
\hline first & 36.09 & 3.14 & 73.2 & 14.53 \\
\hline second & 37.20 & 2.81 & 84.0 & 14.47 \\
\hline \multicolumn{5}{|l|}{ Stage of growth } \\
\hline early & 36.89 & 2.88 & 82.1 & 14.19 \\
\hline late & 36.41 & 2.75 & 75.1 & 14.81 \\
\hline \multicolumn{5}{|l|}{ Extent of wilting } \\
\hline unwilted & $21.52^{\mathrm{A}}$ & 2.99 & $81.3 \mathrm{~b}$ & $12.85^{\mathrm{A}}$ \\
\hline wilted & $37.76^{\mathrm{H}}$ & 2.91 & $77.1 \mathrm{a}$ & $14.22^{B}$ \\
\hline strongly wilted & $50.65^{\mathrm{C}}$ & 3.02 & $77.3^{\mathrm{a}}$ & $16.42^{\mathrm{C}}$ \\
\hline SEM & 1.75 & 0.02 & 1.31 & 0.52 \\
\hline \multicolumn{5}{|c|}{$\begin{array}{l}\text { Statistical significance } \\
\text { of effect }\end{array}$} \\
\hline cut & $*$ & $* *$ & $* *$ & NS \\
\hline stage of growth & NS & $* *$ & $* *$ & NS \\
\hline extent of wilting & $* *$ & NS & $*$ & $* *$ \\
\hline
\end{tabular}

$\mathrm{a}, \mathrm{b}-\mathrm{P}<0.05$ and $\mathrm{A}, \mathrm{B}, \mathrm{C}-\mathrm{P}<0.01$

contents $(\mathrm{P}<0.01)$, also the proportion of protein- $\mathrm{N}$ in total- $\mathrm{N}$ was higher in the second cut $(\mathrm{P}<0.01)$. Earlier stage of growth provided herbage with higher total- $\mathrm{N}$ and protein- $\mathrm{N} \%$ of $\mathrm{N}$ content $(\mathrm{P}<0.01)$ compared to the later stage. There was no change in total- $\mathrm{N}$ content with increasing extent of wilting, but wilted herbage showed a slightly lower proportion of protein- $\mathrm{N}$ in total- $\mathrm{N}$ $(P<0.05)$. Wilting also caused a significant increase in WSC content $(P<0.01)$. When expressed on a DM basis, all of the factors studied had a significant 


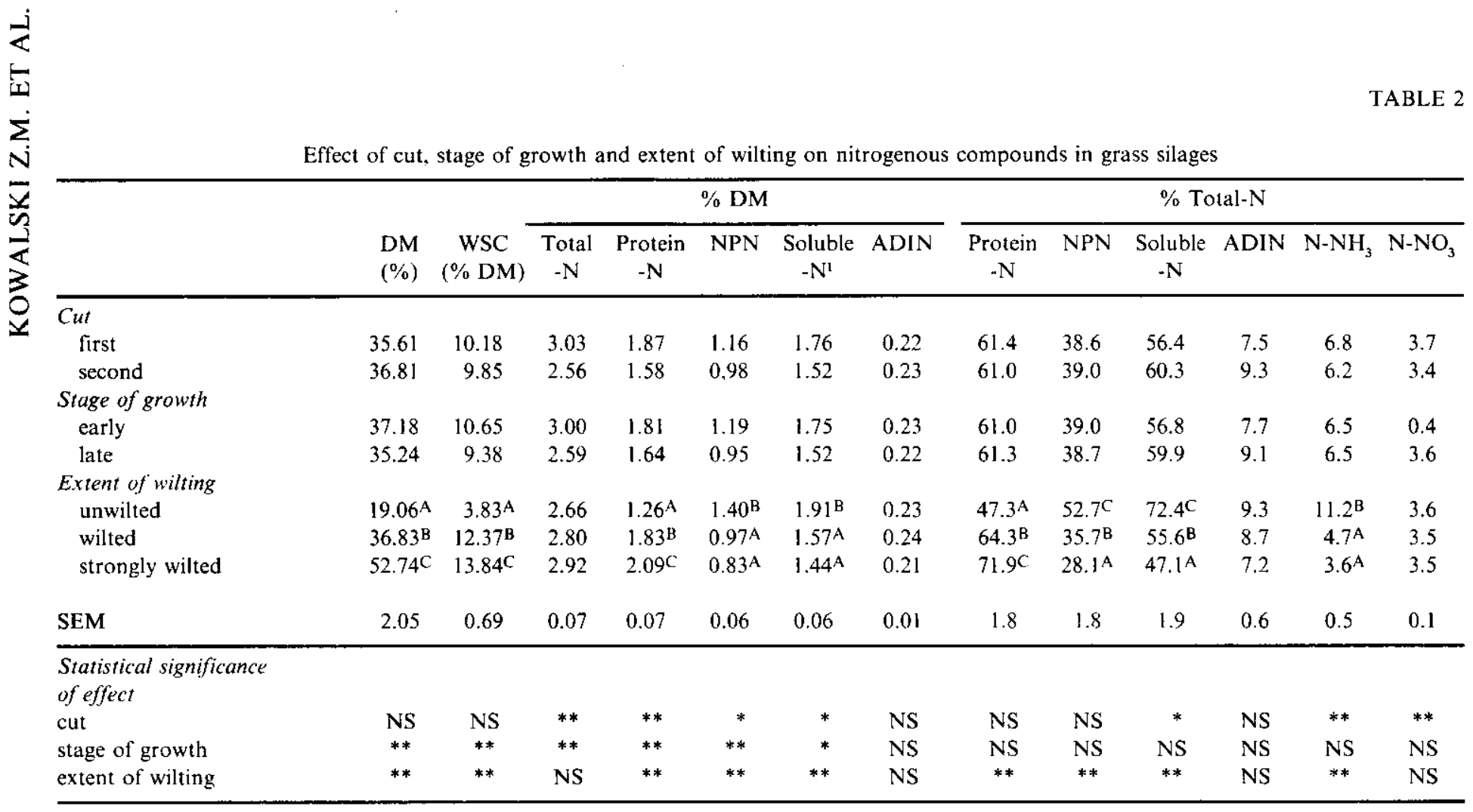

1 in $10 \%$ solution of Wise Burrough Mineral Buffer A, B, C $-\mathrm{P}<0.01$ 
effect on nitrogenous compounds in silages, except ADIN and the effect of wilting on total-N (Table 2). Silages made from the first cut had significantly higher total- $\mathrm{N}$, protein $\mathrm{N}(\mathrm{P}<0.01)$ and soluble- $\mathrm{N}(\mathrm{P}<0.05)$ contents. Total-N, protein-N, NPN $(\mathrm{P}<0.01)$ and soluble- $\mathrm{N}(\mathrm{P}<0.05)$ decreased with advancing maturity of herbage. Wilting caused a significant increase in protein- $\mathrm{N}$ as well as a decrease in NPN and soluble- $\mathrm{N}$ content $(\mathrm{P}<0.01)$.

On the other hand, when expressed as a percent of total-N (Table 2), stage of growth had no effect on any nitrogenous compounds. Protein of silages made from the first cut was slightly less soluble $(P<0.05)$, although its ammonia content was significantly higher than in the second cut $(\mathrm{P}<0.01)$. Of the factors studied, wilting had the greatest effect, causing a significant $(P<0.01)$ increase in protein- $N$ and decreasing its solubility $(P<0.01)$. A significant $(P<0.01)$ effect of wilting on decreasing the ammonia content was also observed: in unwilted silages $\mathrm{N}-\mathrm{NH}_{3}$ comprised $11.2 \%$ of total $\mathrm{N}$, while in wilted and strongly wilted 4.7 and $3.6 \%$ respectively.

Ensiling processes caused some losses of WSC, which was particularly evident in unwilted silages $(12.85 \%$ of DM in unwilted herbage (Table 1$) v s .3 .83 \%$ in unwilted silages (Table 2).

The relationships between some chemical parameters in herbages and silages are given in Table 3. The proportion of protein $-\mathrm{N}$ and soluble- $\mathrm{N}$ in total- $\mathrm{N}$ were

TABLE 3

Correlation coefficients ${ }^{1}$

\begin{tabular}{|c|c|c|c|c|c|c|}
\hline \multirow{3}{*}{$\mathbf{X}$} & \multicolumn{6}{|c|}{$\mathrm{Y}$} \\
\hline & \multirow[b]{2}{*}{$\begin{array}{l}\text { Total-N } \\
(\% \text { DM })\end{array}$} & \multirow[b]{2}{*}{$\begin{array}{c}\text { WSC } \\
(\% \text { DM })\end{array}$} & \multicolumn{4}{|c|}{$\%$ of silage Total- $\mathrm{N}$} \\
\hline & & & Protein- $\mathrm{N}$ & NPN & Soluble-N & $\mathrm{N}-\mathrm{NH}_{3}$ \\
\hline Herbage DM (\%) & & & $\begin{array}{c}0.93 \\
* *\end{array}$ & $\begin{array}{c}-0.93 \\
* *\end{array}$ & $-\underset{* *}{0.86}$ & $\begin{array}{c}-0.87 \\
* *\end{array}$ \\
\hline Herbage WSC (\% DM) & & & $\begin{array}{r}0.69 \\
* *\end{array}$ & $\begin{array}{c}-0.69 \\
* *\end{array}$ & $\begin{array}{c}-0.58 \\
*\end{array}$ & -0.48 \\
\hline \multicolumn{7}{|l|}{ Silage: } \\
\hline $\begin{array}{l}\operatorname{DM}(\%) \\
\text { total-N }(\% \mathrm{DM})\end{array}$ & 0.09 & $\begin{array}{r}0.87 \\
* *\end{array}$ & $\begin{array}{c}0.70 \\
* * \\
0.01\end{array}$ & $\begin{array}{c}-0.80 \\
* * \\
0.07\end{array}$ & $\begin{array}{c}-0.75 \\
* * \\
-0.04\end{array}$ & $\begin{array}{r}-0.81 \\
* * \\
0.04\end{array}$ \\
\hline protein- $N \quad(\% \mathrm{~N})$ & & & & & $-\underset{* *}{0.63}$ & \\
\hline NPN $\quad(\% \mathrm{~N})$ & & & & & $\begin{array}{c}0.83 \\
* *\end{array}$ & \\
\hline soluble-N $(\% \mathrm{~N})$ & & & & & & $\begin{array}{l}0.64 \\
* *\end{array}$ \\
\hline
\end{tabular}

1 including data for early stage of growth of the third cut $(n=60)$ 
highly correlated with herbage DM and WSC. On the other hand, they were not correlated with total-N content in silages $(\% D M)(P>0.05)$. Solubility of protein was negatively correlated with $\mathrm{DM}(\mathrm{r}=-0.75)$ and protein-N $(\mathrm{r}=-0.63)$ but positively with NPN content in silage total-N $(r=0.83)$.

\section{DISCUSSION}

The quality of grass silage depends both on the chemical composition of herbage and the conservation technique (McDonald et al., 1991). In modern protein systems of ruminant nutrition (see Vérité et al., 1988), the quality of grass silages should be estimated taking into account the proportion of soluble and insoluble protein and NPN. In the present study the effect of cut, stage of growth and wilting on the nitrogenous compounds in silages was determined.

\section{Cut effect}

Grass silages made from herbage cut in May-June contained more total-N, protein-N, NPN and soluble-N in their dry matter compared to those cut in July (Table 2). However, these differences were mainly due to total- $\mathrm{N}$ content since when expressed as a \% of total-N, the time of cut had no effect on protein- $\mathrm{N}$ and NPN contents. Protein of the second cut silages appeared to be even more soluble. This is consistent with its higher susceptibility to proteolysis in the silo since the difference between two cuts observed in herbage, i.e. $73.2 \mathrm{vs.} 84.0 \%$ (Table 1), disappeared in silages (Table 2).

The effect of cut on $\mathrm{N}-\mathrm{NH}_{3}$ and $\mathrm{N}-\mathrm{NO}_{3}$ in \% of total $\mathrm{N}$, although statistically proved, seems to be nutritionally unimportant.

\section{Stage of growth}

With advancing maturity of plants, total- $\mathrm{N}$ content in herbage and silage (\%DM) decresed (Table 1 and 2). This confirms earlier findings (Lyttleton, 1973; Flipot el al., 1984). Similarly to the effect of cut, differences found in nitrogenous compounds in DM were likely due to higher total- $\mathrm{N}$ content in silages made of earlier stage grass (Table 2), for there was no effect of growth stage on the proportion of any nitrogenous compounds in total- $N$. This is in agreement with results of Flipot et al. (1984) who observed no effect of plant maturity on soluble- $\mathrm{N}$ and $\mathrm{N}-\mathrm{NH}_{3}$ as a percentage of grass silage total- $\mathrm{N}$.

\section{Extent of wilting}

Wilting prior to ensiling has been recognized as an effective means of improving the quality of silage. However, the effects on animal performance 
have often been less clear (see review by Gordon, 1989). Intensive proteolysis caused by plant enzymes and microflora as well as excessive heat generated in the silo have usually been regarded as the principle reasons for lower efficiency of wilted silage utilization by animals (Thomas et al., 1982; Anderson, 1983; Charmley et al., 1991). Prewilting of herbage in the present study did not affect the total- $\mathrm{N}$ content (Table 1), which is similar to results obtained by others (Brady, 1960; Anderson, 1983). It caused only a slight decrease in the proportion of protein-N in total-N, since after $24-36$ hours of wilting about $77 \%$ of total-N was in protein form. Such a small reduction in protein- $\mathrm{N}$ could be due to sunny and windy weather. When wilting was carried out at extended moist conditions, considerable losses in protein- $\mathrm{N}$ were observed (Anderson, 1983). The rise in WSC content ( $\%$ DM) in herbage, as a result of wilting, indicates that more substrates are available for bacteria (Table 1).

The results of this study show that wilting can improve the quality of the grass silage by increasing its protein- $\mathrm{N}$ content together with a decrease in NPN, soluble- $\mathrm{N}$ and ammonia- $\mathrm{N}$ (on a DM and total- $\mathrm{N}$ basis). This is in agreement with Brady (1960), who found that a short term prewilting reduced the amount of ammonia-N in silages. However, some other authors, including Carpintero et al. (1979) and Armstrong (1983; 1985), observed a higher ammonia content in wilted silages. Recently, Charmley et al. (1991) showed that heat treatment of lucerne before wilting stopped plant protease activity and markedly reduced the extent of proteolysis in silages. This suggests that plant enzymes are the most important factor in the protein breakdown during ensiling. Prolonged wilting, particularly under adverse weather conditions, enhances plant enzyme activity and directly elevated NPN and ammonia-N contents, as was observed by Armstrong (1983, 1985).

Wilting did not induce excessive heating in the silos, since ADIN did not exceed $10 \%$ of total- $\mathrm{N}$. This indicates that protein was not heat damaged (Thomas et al., 1982). Excessive heat in the silo can be generated when the DM content of ensiling material is too high, e.g. over $50 \%$. Silos used in this study were probably too small to observe such an effect.

Solubility of protein- $\mathrm{N}$ in silages was negatively correlated with either herbage DM and WSC contents or silage DM and protein-N (Table 3). However, this does not depend on total-N content ( $\%$ DM). From the obtained data, including that of the third cut (Kowalski et al., unpublished), it is clear that protein solubility is best correlated with NPN in $\%$ of total-N content $(r=0.83)$. Factors responsible for increasing the proportion of NPN in grass silages should always be considered in the choice of ensiling method as well as in diet formulation. 


\section{CONCLUSIONS}

The results obtained indicate that the extent of wilting, compared to cut and stage of growth, had the greatest effect on nitrogenous compounds in grass silages, increasing protein- $\mathrm{N}$ content and decreasing its solubility. When weather conditions are favourable, wilting for 24-36 hours improves the quality of silages, mainly by increasing the proportion of protein- $\mathrm{N}$ in total $\mathrm{N}$ content and lowering its solubility. Wilting before ensiling should be advised as at routine practice in Poland, irrespective of harvest time.

\section{REFERENCES}

Anderson R., 1983. The effect of moist wilting and formic acid additive on the conservation as silage of two grasses differing in total nitrogen content. J. Sci. Food Agric. 34, 808-818

Anderson R., 1985. Effect of prolonged wilting in poor conditions on the fermentation quality, metabolisability and net energy value of silage given to sheep. Anim. Feed Sci. Tech. 12, $109-118$

Brady C. J., 1960. Redistribution of nitrogen in grass and leguminous fodder plants during wilting and ensilage. J. Sci. Food Agric. 11, 276-284

Carpintero C. M., Henderson A. R., McDonald P., 1979. The effect of some pre-treatments on proteolysis during the ensiling of herbage. Grass Forage Sci. 34, 311-315

Charmley E., Veira D. M., 1991. The effect of heat-treatment and gamma radiation on the composition of unwilted and wilted lucerne silages. Grass Foragc Sci, 46, 381-390

Crooker B. A., Sniffen C. J., Hoover W. H., Johnson L. L., 1978. Solvents for soluble nitrogen measurements in feedstuffs. 3. Dairy Sci. 61, 437-447

Deriaz R. E., 1961. The routine analysis of carbohydrates and lignin in herbage. J. Sci. Food Agric., $12,152-160$

Flipot P., Mason W., Lalande G., 1984. Chemical composition and animal performance of grass forage of varying maturity stored as hay or silage. Anim. Feed Sci. Tech. 11, 35-44

Goering H. K., Van Soest P. J., 1970. Forage fibre analysis. Agric. Handbook 379, U.S.D.A.

Gordon F. J., 1989. Effect of silage additives and wilting on animal performance. In: W. Haresign, D.J.A. Cole (Editors), Recent Advances in Animal Nutrition. Butterworths, London, 159-173

Lyttleton J. W., 1973. Proteins and nucleic acids. In: G. W. Butler, R. W. Bailey (Editors), Chemistry and Biochemistry of Herbage. Academic Press, London, 1, 63-103

McDonald P., Henderson N., Heron S., 1991. The Biochemistry of Silage. Chalcombe Publications, Marlow, pp. 340

Oshima M., McDonald P., 1978. A review of the changes in nitrogenous compounds of herbage during ensilage. J. Sci. Food Agric. 29, 497-505.

Polska Norma PN-74/A-82114. Determination of nitrites and nitrates

Polska Norma PN-74/9152-01. Methods of estimation of quality and nutritive value of silages

Siddons R. C., Evans R. T., Becver D. E., 1979. The effect of formaldehyde-treatment before ensiling on the digestion of wilted grass silage by sheep. Br. J. Nutr. 42, 535-545

Skulmowski J., 1974. Methods of Estimation of Feedstuff Composition and Quality. PWRiL, Warszawa, pp. 155

Tamminga S., Ketelaar R., Van Vuuren A. M., 1991. Degradation of nitrogenous compounds in conserved forages in the rumen of dairy cows. Grass Forage Sci. 46, 427-435

Thomas C., Thomas P. C., 1985. Factors affecting the nutritive value of grass silages. In: W. Haresign. D. J. A. Cole (Editors), Recent Advances in Animal Nutrition. Butterworths, London, 223-256

Thomas J. W., Yu Yu, Middleton T. R., Stalings C., 1982. Estimation of protein damage. In: F. N. 
Owens (Editor), Proceedings of an Intcrnational Symposium on Protein Requirements for Cattle. Oklahoma State Univ.. Stillwater, OK, $81-98$

Vérité R., Peyraud J.-L., 1989. Protein: the PDI systems. In: R. Jarrige (Editor), Ruminant Nutrition. Recommended allowances and feed tables. INRA, Paris, 33-47

\section{STRESZCZENIE}

Wpływ pokosu, fazy wzrostu oraz stopnia podsuszenia zielonki na zawartość składników azotowych i rozpuszczalność bialka $w$ kiszonkach $\mathrm{z}$ traw

Badano kiszonki sporządzone z pierwszego (maj-czerwiec) lub drugiego (lipiec) pokosu trawy pastwiskowej, we wczesnej lub późnej fazie wrrostu, w każdym z pokosów. Trawy zakiszono w formic świcżcj (ok. 21\% SM) lub podsuszoncj przez 24 (ok. 38\%) lub 36 godzin (ok. 51\%). Do zakiszania użyto plastikowych pojemników o pojemności około $60 \mathrm{~kg}$ świeżej zielonki. W zielonkach i kiszonkach $(\mathrm{n}=48)$ oznaczano zawartość $\mathrm{N}$-ogólnego, N-białkowego, NPN, ADIN, N-NH ${ }_{3}$, a także N-rozpuszczalnego w buforze mineralnym (Wise Burroughs Mineral Buffer).

Pokos, faza wzrostu oraz stopień podsuszenia ziclonki miały istotny wpływ $(P<0.05$ i $P<0.01)$ na zawartość składników azotowych w suchej masie kiszonek z traw, z wyjątkiem ADIN. Gdy uzyskane wyniki przeliczono w stosunku do azotu ogólnego $(\% \mathrm{~N})$, stopień podsuszenia zielonki miał największy wpływ na zawartość składników azotowych w kiszonkach. Wraz ze wzrostem zawartości suchej masy istotnie wzrastała zawartość $\mathrm{N}$-białkowego $(\mathrm{P}<0.01)$, a obniżala się zawartość $\mathrm{N}$-amoniakalnego oraz rozpuszczalnego $(\mathrm{P}<0.01$ ). Niezależnie od pokosu oraz terminu zbioru podsuszenie pozwala na uzyskiwanie kiszonek o wysokiej wartości pokarmowej białka. 